\title{
MOTYWACJA A KREATYWNOŚĆ ZASOBÓW LUDZKICH W HOTELARSTWIE - ANALIZA STUDIUM PRZYPADKU WYBRANEGO HOTELU Z TRÓJMIASTA
}

\begin{abstract}
Celem niniejszego artykułu jest ukazanie zależności pomiędzy motywacją a kreatywnością zasobów ludzkich na przykładzie pracowników wybranego hotelu w Trójmieście. Problemem badawczym była próba znalezienia odpowiedzi na pytanie, jaka jest rola i znaczenie motywacji w inspirowaniu zasobów ludzkich do kreatywnego wysiłku. Zastosowane metody badawcze to krytyczna analiza literatury przedmiotu, w tym opracowań i raportów z badań przeprowadzonych $\mathrm{w}$ omawianej problematyce oraz badania empiryczne przeprowadzone metodą ankiety wśród pracowników trójmiejskiego hotelu. Rezultaty badań wpisują się w problematykę zarząadzania zasobami ludzkimi, szczególnie w kontekście motywacyjnych uwarunkowań dla kreatywności zasobów ludzkich w organizacji, i dowiodły między innymi szczególnego znaczenia motywatorów wewnętrznych, takich jak interesująca praca i poczucie zaangażowania w pracę, jako istotnych czynników wzmacniających kreatywność badanych; podczas gdy poczucie stabilności zatrudnienia i taktowne dyscyplinowanie to motywatory zewnętrzne, które istotnie osłabiały kreatywność respondentów. Badania miały charakter studium przypadku, stąd ich wyników nie należy uogólniać. Można je potraktować jako pilotaż testujący założenia i narzędzie badawcze. Mimo to wyniki niniejszych badań z pewnością dostarczają istotnych informacji, stanowiących zarówno podstawę do merytorycznej dyskusji, jak i kontekst dla szerszego zakresu badań. W artykule sformułowano także wskazówki dla kadry menedżerskiej, zwłaszcza w kontekście procesu wzbogacania pracy, mając na względzie zarówno wzmocnienie zainteresowania pracą, jak i zaangażowania pracowników; oba te aspekty istotnie wspierały bowiem kreatywność badanych pracowników. Jednakże we wskazaniach respondentów znalazły się one poza wiodącymi motywatorami do aktualnej pracy.
\end{abstract}

Słowa kluczowe: hotelarstwo, motywacja, kreatywność, pracownicy

\section{WPROWADZENIE}

W kontekście ogromnej dynamiki zmian sukces organizacji nigdy dotąd nie zależał tak bardzo od kreatywności i innowacyjności ${ }^{3}$. Globalizacja gospodarki, pojawiające się wyzwania to jednocześnie nowe problemy wymagające od współczesnych przedsiębiorstw odmiennego, nowatorskiego podejścia ${ }^{4}$. Konkurencja i silna orientacja na jakość wymaga-

\footnotetext{
${ }^{1}$ Aleksandra Grobelna, Akademia Morska w Gdyni, ul. Morska 81-87, 81-225 Gdynia, tel.: +48 5869103 44, e-mail: a.grobelna@wpit.am.gdynia.pl. (autor korespondencyjny).

2 Arkadiusz Mazurkiewicz, Akademia Morska w Gdyni, ul. Morska 81-87, 81-225 Gdynia, tel.: +48 5869016 72, e-mail: a.mazurkiewicz@wpit.am.gdynia.pl.

${ }^{3}$ S. Wong, L. Pang, Motivators to creativity in the hotel industry - perspectives of managers and supervisors, „Tourism Management” 24/5 (2003), s. 552.

${ }^{4}$ E. Jerzyk, G. Leszczyński, H. Mruk, Kreatywność w biznesie, Wydawnictwo Akademii Ekonomicznej w Poznaniu, Poznań 2004, s. 12
} 
ją również od współczesnych hoteli innowacyjnej postawy, zwłaszcza w odniesieniu do poprawy procesu świadczenia usług ${ }^{5}$. W związku $\mathrm{z}$ tym coraz większe zainteresowanie zarówno teoretyków, jak i praktyków biznesu kierowane jest na kreatywność zasobów ludzkich; szczególnie w firmach usługowych (w tym w hotelarstwie) ${ }^{6}$, gdzie jakość świadczonych usług determinowana jest przede wszystkim poprzez umiejętności i postawę pracowników tworzących usługę ${ }^{7}$.

To pracownicy (zwłaszcza pracownicy kontaktowi) mają szczególną możliwość zmieniania się, zdolność uczenia i doskonalenia potencjału intelektualnego, potrafią działać i myśleć kreatywnie i twórczo ${ }^{8}$, a obserwując zmieniające się potrzeby i wymagania klientów, mają szczególną sposobność, by sugerować nowe sposoby doskonalenia procesu usługowego ${ }^{9}$. Dlatego też kreatywny personel znacznie częściej odczytuje ukryte potrzeby klienta, tworzy dobre relacje, i efektywnie rozwiązuje problemy usługowe, kreując pozytywne doświadczenia klientów ${ }^{10}$. Nie jest więc przesadą stwierdzenie, że jednym z warunków uzyskania przewagi konkurencyjnej na rynku będzie posiadanie przez przedsiębiorstwo jednostek twórczych generujących nowe, oryginalne pomysły oraz kreatywne sposoby rozwiązywania problemów ${ }^{11}$.

Kreatywność definiowana jest jako potencjał człowieka, dzięki któremu potrafi on wykonywać zarówno coś nowego, jak i wartościowego dla siebie i innych ${ }^{12}$. W warunkach silnej konkurencji kreatywność staje się niemal warunkiem koniecznym, by wyjść naprzeciw rosnącym wymaganiom klientów. W związku z tym szczególnie ważna więc staje się motywacja do podjęcia kreatywnego wysiłku. Jednak mimo że motywacja wydaje się w pewien sposób najważniejszym czynnikiem wpływającym na poziom kreatywności, to jak sugeruje literatura przedmiotu, w kontekście badań nad kreatywnością należałoby jej znaczeniu poświęcić znacznie więcej uwagi ${ }^{13}$.

Celem niniejszej pracy jest ukazanie zależności pomiędzy motywacją a kreatywnością zasobów ludzkich na przykładzie pracowników wybranego hotelu z Trójmiasta. Problemem badawczym jest próba znalezienia odpowiedzi na pytanie, jaka jest rola i znaczenie motywatorów w inspirowaniu zasobów ludzkich do kreatywności. Innymi słowy - jak motywować pracowników, by sprzyjać ich twórczym zachowaniom w organizacji.

\footnotetext{
${ }^{5}$ S.C.-K. Wong, A. Ladkin, Exploring the relationship between employee creativity and job related motivators in The Hong Kong hotel industry, „International Journal of Hospitality Management” 27/3 (2008), s. 426.

${ }^{6}$ A.H.Y. Hon, W.W.H. Chan. L. Lu, Overcoming work - related stress and promoting employee creativity in hotel industry: The role of task feedback from supervisor, „International Journal of Hospitality Management” 2013/33, s. 416; C.-J. Wang, H.-T. Tsai, M.-T.Tsai, Linking transformational leadership and employee creativity in the hospitality industry: The influences of creative role identity, creative self-efficacy, and job complexity, „Tourism Management” 2014/40, s. 79.

${ }^{7}$ J. Otto, Marketing relacji. Koncepcja i stosowanie, CH Beck, Warszawa 2001, s. 194.

${ }^{8}$ Ibidem, s. 177.

${ }^{9}$ S. Raub, Does Bureaucracy kill individual initiative? The impact of structure on organizational citizenship behavior in the hospitality industry, „International Journal of Hospitality Mangement” 27/2 (2008), s. 180.

${ }^{10}$ H.G. Çekmecelioğlu, A. Günsel, Promoting Creativity Among Employees Of Mature Industries: The Effects Of Autonomy And Role Stress On Creative Behaviors And Job Performance, „Procedia Social and Behavioral Sciences” 2011/24, s. 890.

${ }^{11}$ A. Bubrowiecki, Popraw swoja kreatywność, Muza S.A., Warszawa 2008, s. 15.

${ }^{12}$ A. Bubrowiecki, Popraw swoja kreatywność, Muza S.A., Warszawa 2008, s. 10.

${ }^{13}$ S. Wong, L. Pang, op. cit., s. 552.
} 
Rezultaty badań wpisują się w problematykę zarządzania zasobami ludzkimi, szczególnie w kontekście motywacyjnych uwarunkowań dla kreatywności; w aspekcie aplikacyjnym zaś dostarczają informacji, jakie motywatory pracy mogą istotnie stymulować personel hotelowy do kreatywnego wysiłku, by w rezultacie wzmocnić konkurencyjność organizacji. Zastosowane metody badawcze to analiza literatury przedmiotu, w tym opracowań i raportów z badań przeprowadzonych wokół podjętego problemu, oraz badania empiryczne, przeprowadzone metodą ankietową wśród pracowników trójmiejskiego hotelu.

\section{ROLA I ZNACZENIE MOTYWACJI WEWNECTRZNEJ DLA KREATYWNOŚCI ZASOBÓW LUDZKICH}

Według literatury przedmiotu innowacyjność staje się kluczowa dla długoterminowego sukcesu organizacji ${ }^{14}$. Mimo że kreatywność i innowacyjność są ze sobą blisko powiązane, to jednak występują między nimi pewne różnice ${ }^{15}$. Podążając za teorią kreatywności i innowacji w organizacji (The Componential Theory of Organzational Creativity and Innovation ${ }^{16}$ ) - kreatywność (jednostek i grup) staje się wiodącym źródłem dla innowacji w organizacji ${ }^{17}$; wszystkie innowacje zaczynają się bowiem od kreatywnych pomysłów ${ }^{18}$. Innymi słowy, kreatywność jest niejako punktem wyjścia dla innowacji, będącej udaną implementacją kreatywnych pomysłów przez organizację ${ }^{19}$.

Można zatem powiedzieć, że innowacja to praktyczna aplikacja pomysłów, by w rezultacie doprowadziły one do bardziej efektywnego osiągnięcia celów organizacji ${ }^{20}$.

Określenie, w jaki sposób i w jakich warunkach przebiega powstanie twórczych rozwiązań, jest obszarem badań psychologii twórczości, jednakże w ekonomii widać coraz większą potrzebę opisania tych procesów - mogłoby to pozwolić na wzrost efektywności zarządzania kreatywnością ${ }^{21}$. W literaturze przedmiotu podkreśla się pozytywny wpływ kreatywności na wyniki organizacji ${ }^{22}$, ukazując, że w hotelarstwie przynosi ona również istotne korzyści ${ }^{23}$. Mimo jednak jej kluczowego znaczenia nadal zauważa się pewien niedostatek badań prowadzonych wokół tej problematyki w hotelarstwie ${ }^{24}$, a zwłaszcza w kontekście czynników motywujących pracowników do kreatywności ${ }^{25}$.

\footnotetext{
${ }^{14}$ T.M. Amabile, Motivating Creativity in Organizations: On Doing What You Love And Loving What You Do, „California Management Review” 40/1 (1997), s. 40.

${ }^{15}$ Ch.E. Shalley, L.L. Gilson, What leaders need to know: A review of social and contextual factors that can foster or hinder creativity, „The Leadership Quarterly” 15/1 (2004), s. 34.

${ }^{16}$ T.M. Amabile, op. cit., s. 52.

${ }^{17}$ Ibidem.

${ }^{18}$ T.M. Amabile, R. Conti, H. Coon, J. Lazenby, M. Herron, Assessing the work environment for creativity, „The Academy of Management Journal” 39/5 (1996), s. 1154

19 J. Zhou, J.M. George, When Job Dissatisfaction Leads to Creativity: Encouraging the Expression of Voice, „Academy of Management Journal” 44/4 (2001), s. 683.

${ }^{20}$ A. Green, Kreatywność w public relations, PWE, Warszawa 2004, s. 32.

${ }^{21}$ E. Jerzyk, G. Leszczyński, H. Mruk, op. cit., s. 55.

${ }^{22}$ A. Ghafoor, T.M. Qureshi, H.R. Azeemi, S.T. Hijazi, Mediating role of creative self-efficacy, „African Journal of Business Management” 5/27 (2011), s. 11093.

${ }^{23}$ A.H.Y. Hon, W.W.H. Chan, L. Lu, op. cit., s. 416; S.Ch.-K. Wong, A. Ladkin, op. cit., s. 426.

${ }^{24}$ A.H.Y. Hon, W.W.H. Chan. L. Lu, op. cit., s. 417; S.Ch.-K.Wong, A. Ladkin, op. cit., s. 426.

${ }^{25}$ S. Wong, L. Pang, op. cit., s. 552.
} 
Kreatywność to tworzenie pomysłów, które są zarówno nowe, jak i użyteczne ${ }^{26}$. Podkreśla się, że kreatywność zawsze wymaga twórczego myślenia lub działania, które jest celowe i doprowadza do powstania czegoś oryginalnego, a końcowy wynik musi być wartościowy z punktu widzenia realizacji danego celu ${ }^{27}$. Efektem kreatywności są więc pomysły stanowiące nowatorskie rozwiązania, ale jednocześnie przydatne $\mathrm{w}$ realnym Świecie ${ }^{28}$.

Zgodnie z literaturą przedmiotu kreatywność osoby jest między innymi funkcją trzech komponentów: wiedzy i umiejętności w dziedzinie, umiejętności kreatywnego myślenia oraz motywacji ${ }^{29}$. Jak sugeruje Teresa M. Amabile w teorii dotyczącej kreatywności jednostki (The Componential Theory of Individual Creativity ${ }^{30}$ ), wystąpieniu kreatywności najbardziej sprzyja taka sytuacja, kiedy komponenty te nakładają się i poziom każdego z nich jest wysoki ${ }^{31}$. Wydaje się jednak, że spośród wszystkich komponentów kreatywności szczególną rolę odgrywa motywacja. Determinuje ona bowiem stopień, w jakim dana osoba angażuje swoją wiedzę i umiejętności na potrzeby kreatywnego działania ${ }^{32}$. Jej brak może spowodować, że praca nie zostanie wykonana, a pozostałe komponenty będą niewykorzystane lub też skierowane gdzie indziej ${ }^{33}$.

Motywacja jest jednym z istotnych czynników wpływających na wykonanie zadania ${ }^{34}$, na efektywność pracy ${ }^{35}$ i jest jednym z doskonałych impulsów do tworzenia kreatywnych rozwiązań ${ }^{36}$. Spośród wszystkich komponentów kreatywność jest również tym, na który wpływ otoczenia społecznego (środowiska pracy) jest prawdopodobnie najsilniejszy ${ }^{37}$. Spotyka się wiele różnych ujęć motywacji człowieka. Definiuje się ją między innymi jako każdy wpływ, który wywołuje, ukierunkowuje i ożywia zachowanie człowieka, przy czym obejmuje ona siły tkwiące w człowieku lub oddziałujące na niego, które inicjują oraz kierują jego zachowaniem ${ }^{38}$. Pojęcie motywacji opisuje zarówno mechanizmy zachowań prostych, jak i złożonych. Dotyczy mechanizmów zewnętrznych, jak i wewnętrznych, procesów afektywnych oraz poznawczych ${ }^{39}$.

\footnotetext{
${ }^{26}$ T.M. Amabile, Motivating Creativity in Organizations..., s. 40; G.R. Oldham, A.Cummings, Employee Creativity: Personal and Contextual Factors at Work, „The Academy of Management Journal” 39/3 (1996), s. 608; Zhou J., George J.M., op. cit., s. 683.

${ }^{27}$ F.Trompenaars, Kultura innowacji. Kreatywność pracowników a sukces firmy, Wolters Kluwer Polska, Warszawa 2010, s. 25.

${ }^{28}$ E. Jerzyk, G. Leszczyński, H. Mruk, op. cit., s. 10.

${ }^{29}$ T.M. Amabile, How to Kill Creativity, „Harvard Business Review” 1998/76, s. 78.

${ }^{30}$ Eadem, Motivating Creativity in Organizations..., s. 42.

${ }^{31}$ Ibidem.

${ }^{32}$ Ibidem, s. 44.

33 T.M. Amabile, How to Kill Creativity..., s. 79.

${ }^{34}$ T. Simons, Motivation research in hospitality between 1990 and 2001: a prescriptive review of the literature, w: Managing employee attitudes and behaviors in the tourism and hospitality industry, red. S. Kusluvan, Nova Publishers, NY 2003, s. 240.

${ }^{35}$ W. Kozłowski, Zarządzanie motywacja pracowników, CeDeWu, Warszawa 2009, s. 11.

${ }^{36}$ E. Jerzyk, G. Leszczyński, H. Mruk, op. cit., s. 24.

${ }^{37}$ T.M. Amabile, Motivating Creativity in Organizations..., s. 44.

${ }^{38}$ W. Kozłowski, op. cit., s. 14.

${ }^{39}$ A. Lipka, M. Król, S. Waszczak, A. Winnicka-Wejs, Kształtowanie motywacji wewnętrznej. Koszty jakości i ryzyko, Difin, Warszawa 2010, s. 15
} 
Motywacja w pracy może mieć różnorodny charakter ${ }^{40}$. Motywacja zewnętrzna (instrumentalna) stwarza zachętę do działania, które jest nagradzane lub pozwala uniknąć kary $^{41}$. Jest to zatem podejmowanie działania dla jakiegoś celu zewnętrznego ${ }^{42}$. Pojęcie to stosuje się do aktywności ukierunkowanych na bodziec zawarty w celach lub skutkach ${ }^{43}$. Takiej motywacji sprzyja więc system nagród (np. podwyżka pensji) lub kar (np. działania dyscyplinarne, wstrzymanie płacy, krytyka) ${ }^{44}$.

Motywacja wewnętrzna (autoteliczna) pobudza do działania, które ma wartość samą w sobie ${ }^{45}$, praca jest interesująca, angażująca, ciekawa, dająca przyjemność i osobiste poczucie wyzwania ${ }^{46}$. Istotę motywacji wewnętrznej określają takie komponenty jak bodźce zawarte w czynności; poczucie autonomii i kompetencji; zainteresowanie i zaangażowanie ${ }^{47}$. Motywacji tej sprzyjają między innymi poczucie ważności pracy, swoboda działania, możliwości wykorzystania i rozwoju umiejętności itp. ${ }^{48}$.

Oprócz motywacji wewnętrznej i zewnętrznej wyróżnia się także motywacje mieszane: autoteliczno-instrumentalną, gdzie satysfakcja bierze się przede wszystkim z przyjemności spełniania czynności, a wtórnie z nagród i osiągnięć, oraz instrumentalnoautoteliczną, gdzie wykonanie czynności staje się środkiem do osiągnięcia celu, na przykład nagród ${ }^{49}$.

Choć oba rodzaje motywacji często się ze sobą przeplatają, a dobrze rozwinięte i połączone warunkują dużą gotowość jednostki do działania ${ }^{50}$, to okazuje się, że różne formy motywacji nie mają takiego samego wpływu na kreatywność ${ }^{51}$. W wielu badaniach wykazano, że kreatywności sprzyja sytuacja, kiedy osoba jest zmotywowana przede wszystkim wewnętrznie ${ }^{52}$, o czym stanowi wiodąca zasada kreatywności The Intrinsic Motivation Principle of Creativity ${ }^{53}$. Uzasadnia się, że ludzie stają się bardziej kreatywni, kiedy są zmotywowani poprzez zainteresowanie, poczucie satysfakcji i wyzwań, jakie niesie praca sama w sobie, a nie zewnętrzne naciski ${ }^{54}$.

Wewnętrznie motywowane osoby angażują się w czynność, ponieważ doświadczają jej jako interesującej oraz dającej zadowolenie ${ }^{55}$. Tymczasem zewnętrzne ograniczenia mogą redukować wewnętrzne zainteresowanie zadaniem, co może prowadzić do osłabie-

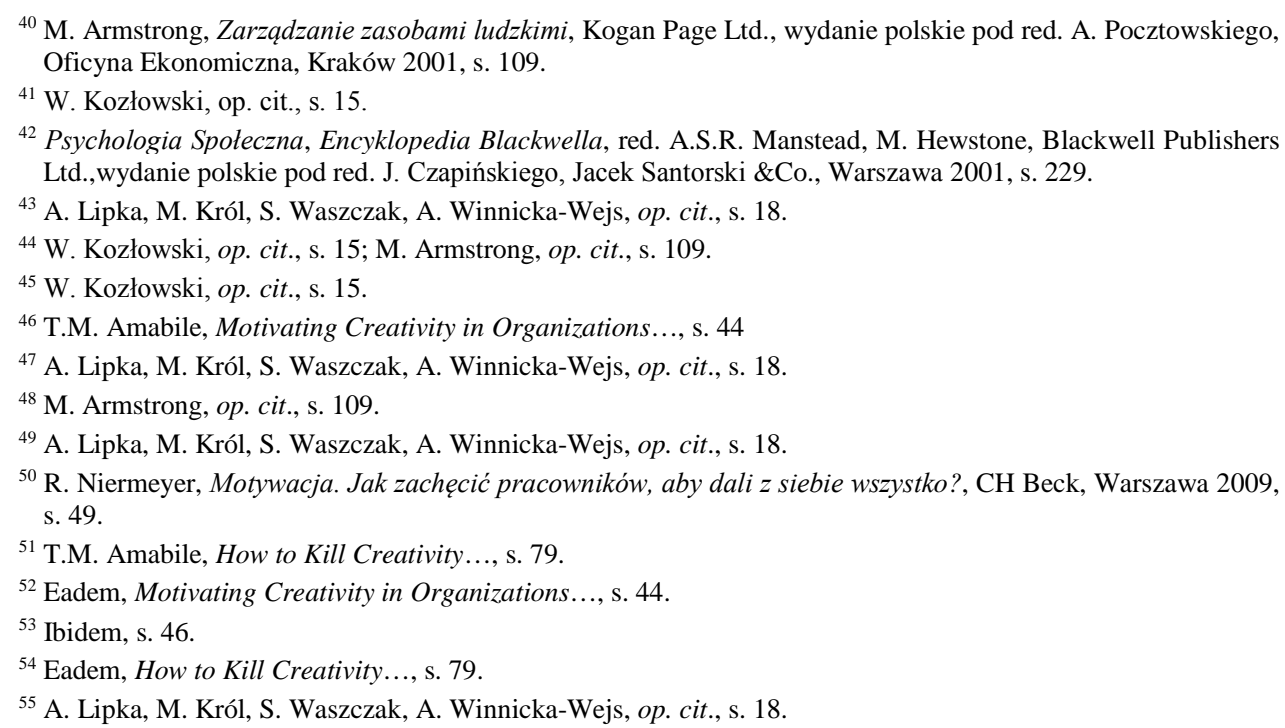


nia kreatywności ${ }^{56}$. Wzrostowi motywacji zewnętrznej może więc towarzyszyć spadek motywacji wewnętrznej ${ }^{57}$.

W tym miejscu należałoby przywołać teorię autodeterminacji (SDT, SelfDetermination Theory), według której prawdziwie wewnętrznie motywowana osoba jest wolna od presji nagród oraz innych zewnętrznych uwarunkowań, a jej działanie jest doświadczane jako autonomiczne i nie zachodzi w warunkach kontroli lub też wzmocnień, stanowiących przyczynę działania ${ }^{58}$. W kontekście umacniania kreatywności możliwa jest jednak pewna synergia motywacyjna, która zależy od kilku czynników, w tym rodzaju motywatorów zewnętrznych, które w określonych warunkach mogą się łączyć z motywacja wewnętrzną, wzmacniając jej pozytywny wpływ na kreatywność lub odwrotnie ${ }^{59}$.

Teoria oceny poznawczej (Cognitive Evaluation Theory), będąca swoistą subteorią teorii determinacji ${ }^{60}$, bada wpływ kontekstu społecznego na motywację wewnętrzną ${ }^{61}$ i ukazuje, że wszystkie czynniki kontekstualne mogą mieć dwa aspekty: informacyjny i kontrolny ${ }^{62}$. Aspekt, który jest relatywnie uwydatniony, determinuje pozytywny lub negatywny wpływ czynnika na wewnętrzną motywację, a przez to - na kreatywność 63 . Społeczno-kontekstualne czynniki, które wspierają poczucie autonomii i kompetencje osoby, wzmacniają również jej motywację wewnętrzną ${ }^{64}$. Dlatego podkreśla się, że zmienne sytuacyjne tylko wówczas są problematyczne, kiedy są postrzegane przez osobę jako kontrolujące jej zachowanie, inaczej zaś gdy dostarczają informacji o kompetencjach $^{65}$. Podążając tym torem rozumowania, można stwiedzić, że charakterystyki środowiska pracy postrzegane jako kontrolujące będą osłabiać motywację wewnętrzną, a w związku $\mathrm{z}$ tym również kreatywność jednostki ${ }^{66}$; odwrotnie zaś będzie się działo w wypadku dominacji w nich pierwiastka informacyjnego ${ }^{67}$.

Prowadząc dyskusję nad motywacją wewnętrzną, należy również przywołać model charakterystyki pracy J. Richarda Hackmana i Grega R. Oldhama, w którym sugeruje się, że szczególny wpływ na motywację wewnętrzną, satysfakcję z pracy i jej efekty mają pewne krytyczne stany psychologiczne, spowodowane doświadczeniem ważności pracy, odpowiedzialności za jej wyniki, a także znajomością faktycznych wyników pracy ${ }^{68}$. Badacze zaliczyli do szczegółowych charakterystyk pracy, wywołujących ważne stany psychologiczne: różnorodność umiejętności, tożsamość zadania, ważność zadania, auto-

\footnotetext{
${ }^{56}$ S.C.-K. Wong, A. Ladkin, op. cit., s. 428.

${ }^{57}$ T.M. Amabile, Motivating Creativity in Organizations..., s. 44-45.

${ }^{58}$ A. Lipka, M. Król, S. Waszczak, A. Winnicka-Wejs, op. cit., s. 19.

${ }^{59}$ T.M. Amabile, Motivating Creativity in Organizations..., s. 45.

${ }^{60}$ A. Lipka, M. Król, S. Waszczak, A. Winnicka-Wejs, op. cit., s. 19.

${ }^{61}$ S.C.-K. Wong, A. Ladkin, op. cit., s. 428.

${ }^{6}$ Ch.E. Shalley, J. Zhou, G.R. Oldham, The effects of personal and contextual characteristics on creativity: where should we go from here?, „Journal of Management”, 30/6 (2004), s. 935.

${ }^{63}$ Ibidem, s. 936.

${ }^{64}$ M. Gagne, E.L. Deci, Self-determination theory and work motivation, „Journal of Organizational Behavior” 2005/26, s. 332.

${ }^{65}$ M.L. Ambrose, C.T. Kulik, Old Friends, New Faces: Motivation Research in the 1990s, „Journal of Management” 25/3 (1999), s. 254.

${ }^{66}$ Ibidem, s. 267.

${ }^{67}$ Ch.E. Shalley, J. Zhou, G.R. Oldham, op. cit., s. 936.

${ }^{68}$ J.R. Hackman, G.R. Oldham, Development of The Job Diagnostic Survey, „Journal of Applied Psychology” 60/2 (1975), s. 160; M. Armstrong, op. cit., s. 216-217.
} 
nomię i sprzężenie zwrotne ${ }^{69}$. Do powstania i zwiększenia motywacji, zwłaszcza wewnętrznej, przyczynia się więc odpowiednie kształtowanie treści pracy poprzez wprowadzenie $w$ nich zmian o charakterze jakościowym ${ }^{70}$. Warto przy tym nadmienić, że model ten został także $z$ powodzeniem sprawdzony w badaniach w branży hotelarskiej ${ }^{71}$. Model Hackmana i Oldhama w pewien sposób nawiązuje również do koncepcji Fredericka Herzberga $^{72}$, wymienione właściwości pracy przypominają założenia teorii Herzberga dotyczące wzbogacenia pracy ${ }^{73}$. Zgodnie $z$ teorią Herzberga zadowolenie i motywacja do pracy biorą się przede wszystkim ze wzbogacania treści pracy, a także zainteresowania wykonywanymi zadaniami i możliwościami rozwoju ${ }^{74}$.

Teoria motywacji opracowana przez Herzberga i in. (1957), jest jedną z niezwykle popularnych i wpływowych teorii motywacji, i choć została poddana krytyce ${ }^{75}$, przez wielu wciąż uważana za teorię właściwą ${ }^{76}$. Wykorzystana została ona w badaniach motywacji pracowników różnych branż, w tym branży turystyczno-hotelarskiej ${ }^{77}$. Skupia się W szczególności na analizie potrzeb ludzkich w konkretnym środowisku - w miejscu pracy. Autor wyróżnił tu dwie grupy czynników mających wpływ na motywację:

- czynniki higieny (niezadowolenia), które odnoszą się do środowiska pracy i pozwalają likwidować niezadowolenie, jednak nie mają wpływu na zadowolenie (satysfakcję) pracownika ${ }^{78}$. Czynniki te, podobnie jak czynniki niższego rzędu w teorii Abrahama Maslowa, stanowią swoiste minimum, w tym wypadku niezbędne do wykonywania pracy oraz pozostania w organizacji ${ }^{79}$. Do czynników tych zalicza się miedzy innymi politykę przedsiębiorstwa, stabilność (pewność) pracy, elementy stałe wynagrodzenia oraz nadzór ${ }^{80}$,

- motywatory (czynniki zadowolenia), które odnoszą się do treści pracy, przyczyniają się do zwiększenia satysfakcji związanej z wykonywaniem pracy, co z kolei prowadzi do lepszej wydajności pracowników ${ }^{81}$. Do czynników wewnętrznych należą między innymi uznanie, osiągnięcia, rozwój oraz odpowiedzialność ${ }^{82}$.

Z teorii motywacji Herzberga wynika, że w pierwszej kolejności należałoby dostarczyć czynniki higieny psychicznej, natomiast drugi etap to zastosowanie motywatorów,

\footnotetext{
${ }^{69}$ J.R. Hackman, G.R. Oldham, op. cit., s. 161-162; M.L. Ambrose, C.T. Kulik, op. cit., s. 257.

${ }^{70}$ A. Lipka, M. Król, S. Waszczak, A. Winnicka-Wejs, op. cit., s. 22.

${ }^{71}$ Lee-Ross D., The reliability and rationale of Hackman and Oldham's Job Diagnostic Survey and Job Characteristics Model among seasonal hotel workers, „International Journal of Hospitality Management” 17/4 (1998), s. 391-406.

${ }^{72}$ A. Lipka, M. Król, S. Waszczak, A. Winnicka-Wejs, op. cit., s. 24.

${ }^{73}$ B. Kamińska, M. Warzyński, Materialne i niematerialne narzędzia motywowania pracowników, Wydawnictwo SWSPiZ w Łodzi, Łódź 2011, s. 35.

${ }^{74}$ A. Lipka, M. Król, S. Waszczak, A. Winnicka-Wejs, op. cit., s. 24.

${ }^{75} \mathrm{Na}$ ten temat między innymi W. Kozłowski, op. cit., s. 44; D. Podmoroff, 365 sposobów na codzienne motywowanie i nagradzanie pracowników, Wolters Kluwer Polska, Warszawa 2010, s. 30.

${ }^{76}$ M. Armstrong, op. cit., s. 110.

77 Ch. Lundberg, A. Gudmundson, T.D. Andersson, Herzberg's Two-Factor Theory of work motivation tested empirically on seasonal workers in hospitality and tourism, „Tourism Management” 30/6 (2009), s. 890-899.

${ }^{78}$ W. Kozłowski, op. cit., s. 42; Ch. Lundberg, A. Gudmundson, T.D. Andersson, op. cit., s. 891.

${ }^{79}$ B. Kamińska, M. Warzyński, op. cit., s. 33.

${ }^{80}$ D. Podmoroff, op. cit., s. 28.

${ }^{81}$ W. Kozłowski, op. cit., s. 42.

${ }^{82}$ D. Podmoroff, op. cit., s. 28; W. Kozłowski, op. cit., s. 43.
} 
które pozwolą zaspokoić potrzeby wyższego rzędu ${ }^{83}$, prowadząc tym samym do motywacji pracownika i poniesienia większego wysiłku dla organizacji.

W badaniach nad motywacją pracowników wykorzystuje się także motywatory Kennetha A. Kovacha, które identyfikują 10 czynników postrzeganych za ważne w motywowaniu ludzi do pracy ${ }^{84}$. Czynniki te wydają się wysoce podobne do tych zidentyfikowanych przez Herzberga - podzielono je na wewnętrzne (6 czynników), które są podobne do motywatorów z teorii Herzberga, i zewnętrzne (4 czynniki) podobne do czynników higieny ${ }^{85}$ (tab. 1).

Motywatory Kovacha początkowo były wykorzystane w badaniach pracowników branż przemysłowych w Stanach Zjednoczonych, następnie zaczęto je wykorzystywać w badaniach nad motywacją w innych branżach, w tym także w hotelarstwie ${ }^{86}$

Tabela 1. Motywatory do pracy według Kennetha A. Kovacha

Table 1. Kovach's job-related motivators

\begin{tabular}{|l|}
\hline \multicolumn{1}{|c|}{$\begin{array}{c}\text { Motywatory zewnętrzne } \\
\text { (Extrinsic motivators) }\end{array}$} \\
\hline Bezpieczeństwo zatrudnienia \\
\hline Dobre zarobki \\
\hline Dobre warunki pracy \\
\hline Taktowne dyscyplinowanie \\
\hline \multicolumn{1}{|c|}{$\begin{array}{c}\text { Motywatory wewnętrzne } \\
\text { (Intrinsic motivators) }\end{array}$} \\
\hline Docenienie wykonanej pracy \\
\hline Poczucie zaangażowania \\
\hline Życzliwa pomoc w osobistych problemach \\
\hline Interesująca praca \\
\hline Szanse na awans i rozwój \\
\hline Lojalność względem pracowników \\
\hline
\end{tabular}

Źródło: opracowanie na podstawie: K.A. Kovach, What motivates employees? Workers and Supervisors Give Different Answers, „Business Horizons” $30 / 5$ (1987), s. 59; S.Ch.-K. Wong, A. Ladkin, Exploring the relationship between employee creativity and job related motivators in The Hong Kong hotel industry, „International Journal of Hospitality Management” 27/3 (2008), s. 429.

Reasumując, sugeruje się, że badania nad kreatywnością są naturalnym poszerzeniem wcześniejszych badań nad motywacją pracowników ${ }^{87}$. Motywacja i kreatywność są ze

${ }^{83}$ B. Kamińska, M. Warzyński, op. cit., s. 34.

${ }^{84}$ K.A. Kovach, What motivates employees? Workers and Supervisors Give Different Answers, „Business Horizons” 30/5 (1987), s. 59; S.Ch.-K. Wong, A. Ladkin, op. cit., s. 429.

${ }^{85}$ S.Ch. Wong, A. Ladkin, op. cit., s. 429.

${ }^{86} \mathrm{Na}$ przykład K.R. Charles, L.H. Marshall, Motivational preferences of Caribbean hotel workers: an exploratory study, „International Journal of Contemporary Hospitality Management” 4/3 (1992), s. 25-29; T. Simons, C.A. Enz, Motivating hotel employees, „Cornell Hotel and Restaurant Administration Quarterly” 36/1 (1995), s. 20-27; V. Siu, N. Tsang, S.Wong, What motivates Hong Kong Hotel employees?, „Cornell Hotel and Restaurant Administration Quarterly” 38/5 (1997), s. 44-49; S.C-K. Wong, A. Ladkin, op. cit., s. 426-437.

${ }^{87}$ M.L. Ambrose, C.T. Kulik, op. cit., s. 268. 
sobą istotnie powiązane, te same kontekstualne zmienne, które wzmacniają motywację wewnętrzną, są bowiem także związane z kreatywnością. Dlatego organizacja może jednocześnie w efektywny sposób wpływać zarówno na motywację, jak i kreatywność zasobów ludzkich ${ }^{88}$. I choć wciąż występują pewne sprzeczności w zależnościach między motywacją wewnętrzną i zewnętrzną a kreatywnością zasobów ludzkich, to jedno jest pewne - motywacja wewnętrzna jest wewnętrzną siłą napędową, stanowiącą najbardziej podstawową formę ludzkiej satysfakcji ${ }^{89}$ oraz mającą niezaprzeczalne znaczenie dla kreatywności ${ }^{90}$.

\section{METODYKA BADAŃ WLASNYCH}

Celem niniejszych badań było ukazanie związku pomiędzy motywacją a kreatywnością zasobów ludzkich na przykładzie pracowników wybranego hotelu. W tym celu przeprowadzono badania w jednym z trójmiejskich hoteli, który zgodził się w nich uczestniczyć. Badania mają charakter studium przypadku i objęto nimi wszystkich pracowników mających kontakt z klientami hotelu. Łącznie w badaniu uczestniczyło 36 pracowników hotelu, w tym 24 kobiety i 12 mężczyzn. Dominowali respondenci w przedziałach wiekowych 51-60 lat (12 osób) i 31-40 lat (10 osób), z wykształceniem wyższym (17 osób) i średnim (14 osób).

Badania przeprowadzono metodą ankiety bezpośredniej. W celu zapewnienia ich anonimowości po wypełnieniu kwestionariuszy respondenci byli proszeni o włożenie ich do przygotowanych kopert, zaklejenie i zwrot kierownikom działów.

Aby dowiedzieć się, co motywuje pracowników hotelu do pracy, poproszono ich o uporządkowanie 1-10 motywatorów Kovacha $(1987)^{91}$, gdzie 1 oznaczało czynnik najbardziej motywujący, 10 - czynnik najmniej motywujący. Kreatywność została zmierzona przy użyciu stwierdzeń zaadaptowanych z pracy Oldhama i Cummings (1996) ${ }^{92}$ podobnie jak Wang i in. (2014), którzy w swoich badaniach, także zaadaptowali te stwierdzenia do pomiaru kreatywności pracowników branży hotelarskiej ${ }^{93}$. W niniejszych badaniach pracownicy samodzielnie oceniali swoją kreatywność, podobnie jak w badaniach Kima i in.(2009) ${ }^{94}$ i Hon (2012) ${ }^{95}$. Respondenci zaznaczali odpowiedzi na pięciostopniowej skali Likerta, gdzie 1 oznaczało „,całkowicie się nie zgadzam”, a 5 - „całkowicie się zgadzam”. Stwierdzenia użyte w kwestionariuszu, pierwotnie sformułowane w języku angielskim, przetłumaczono z zastosowaniem tzw. „tłumaczenia zwrotnego”.

Dokonano także analizy rzetelności skal - wartość współczynnika alfa-Cronbacha dla skali „kreatywność” wyniosła 0,883 , natomiast w celu obliczenia zgodności odpowiedzi respondentów dotyczących motywacji do pracy (ranking motywatorów) wykorzystano

\footnotetext{
${ }^{88}$ Ibidem.

${ }^{89}$ D. Podmoroff, op. cit., s. 41.

${ }^{90}$ E. Jerzyk, G. Leszczyński, H. Mruk, op. cit., s. 25.

${ }^{91}$ K.A. Kovach, op. cit., s. 58-65.

${ }^{92}$ G.R. Oldham, A. Cummings, op. cit., s. 634.

${ }^{93}$ C.-J. Wang, H.-T. Tsai, M.-T.Tsai, op. cit., s. 83.

${ }^{94}$ T.-Y. Kim, A.H.Y. Hon, J.M. Crant, Proactive Personality, Employee Creativity, and Newcomer Outcomes: A Longitudinal Study, „Journal of Business and Psychology” 2009/24, s. 97.

${ }^{95}$ A.H.Y. Hon, When competency-based pay relates to creative performance: The moderating role of employee psychological need, „International Journal of Hospitality Management” 31/1 (2012), s. 133.
} 
statystykę W-Kendalla. Obliczona wartość współczynnika $\mathrm{W}=0,2$ (chi $^{2}=70,249$; $\mathrm{p}<0,01$ ) dała podstawę do przyjęcia hipotezy, że odpowiedzi respondentów były zgodne.

\section{MOTYWACYJNE WSPARCIE DLA KREATYWNOŚCI - WYNIKI BADAŃ I DYSKUSJA}

Na podstawie wyników przeprowadzonych badań można stwierdzić, że respondentom trudno było jednoznacznie określić, czy postrzegają siebie jako osoby kreatywne w pracy; wartość tej zmiennej plasowała się na poziomie 3,28 pkt. Jako bardziej kreatywnych postrzegali siebie mężczyźni (3,69 pkt.) niż kobiety (3,07 pkt.), różnica między wskazaniami obu grup była istotna statystycznie $(\mathrm{t}=-2,569 ; \mathrm{p}=0,015)$.

W analizie kreatywności pod względem wieku badanych zauważono, że najniżej swoją kreatywność postrzegają najmłodsi respondenci - osoby w wieku 21-30 lat (2,96 pkt.), następnie wartość zmiennej wzrasta i najwyższą obserwuje się wśród respondentów w zakresie wieku 31-40 lat (3,53 pkt.); w kolejnych przedziałach wiekowych percepcja kreatywności stopniowo spada, do poziomu 3,17 pkt. wśród najstarszej grupy respondentów ( $\geq 61$ lat).

W ramach rankingu motywatorów (tab. 2) respondenci wskazali, że najbardziej do pracy w hotelu motywują ich bezpieczeństwo zatrudnienia, dobre warunki pracy i docenianie ich pracy przez przełożonych. Należy przy tym zauważyć, że dwa pierwsze motywatory należą do grupy motywatorów zewnętrznych (EM, extrinsic motivators ), natomiast ostatni plasuje się po stronie motywatorów wewnętrznych (IM, intrinsic motivators).

Tabela 2. Motywacja do aktualnej pracy

Table 2. Motivation towards actual job

\begin{tabular}{|l|c|}
\hline Motywatory do aktualnej pracy & $\begin{array}{r}\text { Miejsce w rankingu (wartość } \\
\text { średnia) }\end{array}$ \\
\hline Bezpieczeństwo zatrudnienia & $1(3,03)$ \\
\hline Dobre warunki pracy & $2(4,31)$ \\
\hline Docenienie wykonanej pracy & $3(4,61)$ \\
\hline Dobre zarobki & $4(4,78)$ \\
\hline Lojalność względem pracowników & $5(5,53)$ \\
\hline Interesująca praca & $6(5,67)$ \\
\hline Szanse na awans i rozwój & $7(6,17)$ \\
\hline Poczucie zaangażowania w pracę & $8(6,28)$ \\
\hline Życzliwa pomoc & $9(7,25)$ \\
\hline Taktowne dyscyplinowanie & $10(7,39)$ \\
\hline
\end{tabular}

Respondenci wskazali, że najmniej do pracy w hotelu motywują ich taktowne dyscyplinowanie, życzliwa pomoc w wypadku osobistych problemów i poczucie zaangażowania w pracę. W tym wypadku pierwszy motywator reprezentuje motywatory zewnętrzne, dwa ostatnie to motywatory wewnętrzne. 
Tabela 3. Motywacja do pracy a kreatywność.

Table 3. Motivation towards job and creativity

\begin{tabular}{|l|l|r|}
\hline \multicolumn{2}{|l|}{ Motywatory do aktualnej pracy } & \multicolumn{2}{|c|}{ Kreatywność } \\
\hline \multirow{2}{*}{$\begin{array}{l}\text { Poczucie zaangażowania w } \\
\text { pracę }\end{array}$} & Korelacja Pearsona &,$- 334^{*}$ \\
\cline { 2 - 3 } & Istotność (dwustronna) &, 047 \\
\hline \multirow{3}{*}{ Interesująca praca } & Korelacja Pearsona &,$- 374^{*}$ \\
\cline { 2 - 3 } Taktowne dyscyplinowanie & Istotność (dwustronna) &, 025 \\
\hline \multirow{3}{*}{ Bezpieczeństwo zatrudnienia } & Korelacja Pearsona &, $448^{* *}$ \\
\cline { 2 - 3 } & Istotność (dwustronna) &, 006 \\
\cline { 2 - 3 } & Korelacja Pearsona &, $332^{*}$ \\
\hline & Istotność (dwustronna) &, 048 \\
\hline
\end{tabular}

* Korelacja jest istotna na poziomie 0,05 (dwustronnie); ** Korelacja jest istotna na poziomie 0,01 (dwustronnie)

W analizie relacji między motywacją do pracy a kreatywnością zauważa się istotny związek między zmiennymi, a dokładnie między kreatywnością a takimi motywatorami jak:

- poczucie zaangażowania w pracę i interesująca praca (IM), które - jak pokazują wyniki badań - stanowią istotne wsparcie dla kreatywności (między zmiennymi obserwuje się istotne korelacje: odpowiednio $r=-0,334, p=0,047 ; r=-0,374, p=0,025)$.

- taktowne dyscyplinowanie i bezpieczeństwo zatrudnienia (EM), które w przeciwieństwie do wcześniejszych motywatorów, osłabiają kreatywność badanych (pomiędzy zmiennymi obserwuje się istotne korelacje: $r=0,448, p=0,006 ; r=0,332, p=0,048$ ).

Odnosząc się do tych wyników, można stwierdzić, że kreatywności sprzyjają głównie motywatory wewnętrzne. Istotne znaczenie mają tu dwa czynniki: poczucie zaangażowania w pracę i postrzeganie jej jako interesującej. Im większe ich motywacyjne oddziaływanie, tym bardziej respondenci są skłonni do kreatywnego wysiłku. W wynikach badań Wonga i Ladkin (2008) również ukazano, że jeśli pracownicy są bardziej motywowani poprzez IM, to są jednocześnie bardziej skłonni podejmować większe ryzyko i dzięki temu być bardziej kreatywni w pracy ${ }^{96}$. Ponadto, jak wcześniej podkreślono, czynniki wewnętrzne Kovacha podobne są do czynników satysfakcji w teorii Herzberga, u których podstaw leży to wszystko, co motywuje pracowników do pracy w jeszcze większym zakresie $^{97}$. Ich obecność może wytworzyć wysoki poziom motywacji i pobudzić do lepszego wykonania zadań ${ }^{98}$, co jednocześnie również może skłaniać pracowników do większej kreatywności.

Odwrotnie dzieje się zaś w wypadku motywatorów zewnętrznych - bezpieczeństwa zatrudnienia i taktowanego dyscyplinowania. W wynikach badań wykazano, że wzrostowi ich motywacyjnego znaczenia towarzyszy spadek kreatywności badanych. Nawiązując do teorii Herzberga i podobieństwa motywatorów zewnętrznych Kovacha do czynników

\footnotetext{
${ }^{96}$ S.Ch. Wong, A. Ladkin, op. cit., s. 433.

${ }^{97}$ B. Kamińska, M. Warzyński, op. cit., s. 33.

${ }^{98}$ W. Kozłowski, op. cit., s. 44.
} 
higieny, należy przypomnieć, że decydują one wszakże o psychologicznym i społecznym komforcie pracy, jednakże nie zachęcają do jeszcze lepszej pracy ${ }^{99}$.

Wytłumaczenia uzyskanej zależności można więc upatrywać w przypuszczeniu, że osoby zmotywowane głównie poprzez poczucie bezpieczeństwa zatrudnienia, mając pewną świadomość stabilności pracy, nie obawiając się jednocześnie ryzyka jej utraty i konieczności zmian, mogą nie odczuwać też stymulacji do kreatywnego wysiłku. Badani wykonują pracę, bo zapewnia im stabilność, ale być może nie stanowi dla nich pasji i zainteresowania, w wyniku czego mogą wykonywać ją wyłącznie dla zewnętrznego celu, a nie dla własnej przyjemności i wewnętrznej realizacji.

Drugi z czynników: taktowne dyscyplinowanie, choć najmniej motywował badaną grupę, to jednak wzrostowi jego znaczenia jako czynnika motywującego towarzyszył istotny spadek kreatywności. Być może wynika to z tego, że im bardziej badani postrzegają taktowne uwagi przełożonych jako motywatory do pracy, tym bardziej jednak ograniczają własną pomysłowość, samodzielność i inicjatywę, uzależniając swoje wykonanie w głównej mierze od korygującej opinii menedżerów. W tym kontekście taktowne dyscyplinowanie może być więc postrzegane w kategoriach pewnej formy nadzoru czy kontroli pracy. Tymczasem sytuacje związane między innymi z presją bycia ocenianym czy nadzorem osłabiają motywację wewnętrzną i twórczość ${ }^{100}$.

Niniejsze badania miały wyłącznie charakter studium przypadku, stąd ich wyników nie należy uogólniać. Można je potraktować jako pilotaż testujący założenia i narzędzie badawcze. Mimo to z pewnością dostarczają one istotnych informacji, stanowiących zarówno podstawę do merytorycznej dyskusji, jak i kontekst dla szerszego zakresu badań.

Na podstawie rezultatów badań można stwierdzić, że:

- Najbardziej do aktualnej pracy respondentów motywowały czynniki zewnętrzne (EM): bezpieczeństwo zatrudnienia i dobre warunki pracy; spośród motywatorów wewnętrznych (IM) zaś - docenienie za wykonaną pracę. Motywatory te plasowały się na najwyższej pozycji w rankingu.

- Motywatory wewnętrzne (IM), takie jak interesująca praca i poczucie zaangażowania, stanowiły wzmocnienie dla kreatywności - pomiędzy zmiennymi zaobserwowano statystycznie istotny związek. Odwrotnie zaś motywatory zewnętrzne (EM), czyli poczucie bezpieczeństwa zatrudnienia i taktowne dyscyplinowanie, istotnie obniżały kreatywność badanych, jeśli wzrastało ich motywacyjne oddziaływanie.

- Motywatory wzmacniające kreatywność, na przykład interesująca praca i poczucie zaangażowania w pracę, powinny być przedmiotem szczególnej uwagi i troski menedżerskiej, we wskazaniach respondentów znajdują się bowiem poza wiodącymi czynnikami motywującymi ich do pracy. Stąd pod rozwagę menedżerów poddaje się proces wzbogacania pracy ${ }^{101}$, inicjatywę, która ma służyć między innymi zwiększeniu zainteresowania pracą, poprzez poszerzenie jej zakresu, zapewnienie większej różnorodności zadań, powierzenie nowych inicjatyw, często wymagających większej samodzielności ${ }^{102}$ i większe-

\footnotetext{
99 B. Kamińska, M. Warzyński, op. cit., s. 33.

${ }^{100}$ Psychologia Społeczna..., s. 229.

${ }^{101}$ Metoda zarządzania, która wywodzi się z pracy Herzberga z lat pięćdziesiątych XX w. Patrz: D. Podmoroff, op. cit., s. 54. Badacz radzi, by dokonać reorganizacji pracy polegającej na jej poszerzeniu i wzbogaceniu, tak aby pracownik odgrywał większą rolę w planowaniu, realizacji i ocenie swojej pracy. Patrz: B. Kamińska, M. Warzyński, op. cit., s. 34.

102 D. Podmoroff, op. cit., s. 54.
} 
go zaangażowania umiejętności. W rezultacie proces ten ma stworzyć pracownikowi możliwość wykonywania interesującej pracy, podejmowania decyzji, przyjmowania odpowiedzialności, samokontroli itp. ${ }^{103}$. Jednak aby zapewnić skuteczność procesu, menedżerowie powinni dokładnie poznać swoich pracowników, ich potencjał, umiejętności i osobowość, aby optymalnie wzbogacić treści pracy, mając na względzie zróżnicowane charakterystyki podwładnych.

\section{PODSUMOWANIE}

W literaturze przedmiotu sugeruje się, że liderzy mogą wspierać kreatywność swoich podwładnych poprzez różnorodne mechanizmy, w tym między innymi poprzez wpływanie na ich motywację ${ }^{104}$. Niniejsze badania wykazały, że respondenci stają się bardziej kreatywni, gdy motywują ich do pracy określone czynniki wewnętrzne, takie jak interesująca praca i poczucie zaangażowania. Jednocześnie oba te motywatory znajdują się poza wiodącymi czynnikami motywującymi respondentów do aktualnej pracy. W świetle tych wyników pod rozwagę kadry menadżerskiej poddaje się działania w zakresie wzbogacania pracy, które między innymi poprzez wzrost upełnomocnienia i odpowiedzialności pracowników mogą się przyczynić do większego zainteresowania pracą i zaangażowania, a w rezultacie - prawdopodobnie do wzrostu kreatywności badanych.

Należy jednak podkreślić, że wzmacnianie kreatywności wymaga również sprzyjającego klimatu organizacji, wielu zabiegów, zachęt, a przede wszystkim aprobaty ze strony kierownictwa ${ }^{105}$. Tam gdzie liderzy okazują brak zainteresowania kreatywnością, pracownicy najczęściej poprzestają na rutynowym wykonywaniu czynności ${ }^{106}$, a gdy rutyna staje się strategią optymalną, zanika też potrzeba kreatywnych rozwiązań i nowych pomysłów ${ }^{107}$. Nie ulega więc wątpliwości, że w procesach kreacyjnych istotna jest rola lidera inspiratora, mentora ${ }^{108}$, mającego świadomość i przekonanie, że kreatywność nie może być jednorazowym aktem, a cechą podniesioną do poziomu trwałego kryterium kultury przedsiębiorstwa ${ }^{109}$, w którym zarówno środowisko pracy, klimat, jak i praktyki zarządzania zasobami ludzkimi sprzyjają wyzwoleniu kreatywności i pojawieniu się jej rezultatów ${ }^{110}$.

\section{LITERATURA}

[1] Amabile T.M., Conti R., Coon H., J. Lazenby, Herron M., Assessing the work environment for creativity, „The Academy of Management Journal” 39/5 (1996), s. 1154-1184.

[2] Amabile T.M., How to Kill Creativity, „Harvard Business Review” 1998/76, s. 77-87.

[3] Amabile T.M., Motivating Creativity in Organizations: On Doing What You Love And Loving What You Do, „California Management Review” 40/1 (1997), s. 39-58.

\footnotetext{
${ }^{103}$ B. Kamińska, M. Warzyński, op. cit., s. 34.

${ }^{104}$ R. Reiter-Palmon, J.J. Illies, Leadership and creativity: Understanding leadership from a creative problemsolving perspective, „The Leadership Quarterly” 2004/15, s. 56.

${ }^{105}$ W.B. Martin, Zarządzanie jakościa obstugi w hotelach i restauracjach, Oficyna Ekonomiczna, Kraków 2006, s. 103, na ten temat także: E. Jerzyk, G. Leszczyński, H. Mruk, op. cit., s. 24.

${ }^{106}$ Ibidem.

${ }^{107}$ T. Wieke, Kreatywność i Ty. Droga do pomystowości w pracy, Helion, Gliwice 2007, s. 14.

${ }^{108}$ E. Jerzyk, G. Leszczyński, H. Mruk, op. cit., s. 26.

${ }^{109}$ T. Wieke T., op. cit., s. 16

${ }^{110}$ Ch.E. Shalley, L.L. Gilson, op. cit., s. 35.
} 
[4] Ambrose M.L., Kulik C.T., Old Friends, New Faces: Motivation Research in the 1990s, „Journal of Management” 25/3 (1999), s. 231-292.

[5] Armstrong, M., Zarzadzanie zasobami ludzkimi, Kogan Page Ltd., wydanie polskie pod red. A. Pocztowskiego, Oficyna Ekonomiczna, Kraków 2001.

[6] Bubrowiecki A., Popraw swoja kreatywność, Muza S.A., Warszawa 2008.

[7] Çekmecelioğlu H.G., Günsel A., Promoting Creativity Among Employees Of Mature Industries: The Effects Of Autonomy And Role Stress On Creative Behaviors And Job Performance, „Procedia - Social and Behavioral Sciences” 2011/24, s. 889-895.

[8] Charles, K.R., Marshall, L.H., Motivational preferences of Caribbean hotel workers: an exploratory study, „International Journal of Contemporary Hospitality Management” 4/3 (1992), s. 25-29.

[9] Gagne M., Deci E.L., Self-determination theory and work motivation, „Journal of Organizational Behavior” 2005/26, s. 331-362.

[10] Ghafoor A., Qureshi T.M., Azeemi H.R., Hijazi, S.T., Mediating role of creative self- efficacy, „African Journal of Business Management” 5/27 (2011), s. 11093-11103.

[11] Green A., Kreatywność w public relations, PWE, Warszawa 2004.

[12] Hackman J.R., Oldham G.R., Development of The Job Diagnostic Survey, „Journal of Applied Psychology" 60/2 (1975), s.159-170.

[13] Hon A.H.Y., Chan W.W.H., Lu L., Overcoming work - related stress and promoting employee creativity in hotel industry: The role of task feedback from supervisor, „International Journal of Hospitality Management” 2013/33, s. 416-424.

[14] Hon A.H.Y., When competency-based pay relates to creative performance: The moderating role of employee psychological need, „International Journal of Hospitality Management” 31/1 (2012), s. 130-138.

[15] Jerzyk E., Leszczyński G., Mruk H., Kreatywność w biznesie, Wydawnictwo Akademii Ekonomicznej w Poznaniu, Poznań 2004.

[16] Kamińska B., Warzyński M., Materialne i niematerialne narzędzia motywowania pracowników, Wydawnictwo SWSPiZ w Łodzi, Łódź 2011.

[17] KimT.-Y., Hon A.H.Y., Crant J.M., Proactive Personality, Employee Creativity, and Newcomer Outcomes: A Longitudinal Study, „Journal of Business and Psychology” 2009/24, s. 93-103.

[18] Kovach K.A., What motivates employees? Workers and Supervisors Give Different Answers, „Business Horizons” 30/5 (1987), s. 58-65.

[19] Kozłowski W., Zarządzanie motywacją pracowników, CeDeWu, Warszawa 2009.

[20] Lee-Ross D., The reliability and rationale of Hackman and Oldham's Job Diagnostic Survey and Job Characteristics Model among seasonal hotel workers, „International Journal of Hospitality Management” 17/4 (1998), s. 391-406.

[21] Lipka A., Król M., Waszczak S., Winnicka-Wejs A., Ksztaltowanie motywacji wewnętrznej. Koszty jakości i ryzyko, Difin, Warszawa 2010.

[22] Lundberg Ch., Gudmundson A., Andersson T.D., Herzberg's Two-Factor Theory of work motivation tested empirically on seasonal workers in hospitality and tourism, „Tourism Management” 30/6 (2009), s. 890-899.

[23] Martin W.B., Zarządzanie jakościa obstugi w hotelach i restauracjach, Oficyna Ekonomiczna, Kraków 2006.

[24] Niermeyer R., Motywacja. Jak zachęcić pracowników, aby dali z siebie wszystko?, CH Beck, Warszawa 2009.

[25] Oldham G.R., Cummings A., Employee Creativity: Personal and Contextual Factors at Work, „The Academy of Management Journal” 39/3 (1996), s. 607-634.

[26] Otto J., Marketing relacji. Koncepcja i stosowanie, CH Beck, Warszawa 2001.

[27] Podmoroff D., 365 sposobów na codzienne motywowanie i nagradzanie pracowników, Wolters Kluwer Polska, Warszawa 2010. 
[28] Psychologia Społeczna, Encyklopedia Blackwella, red. A.S.R. Manstead, M. Hewstone, Blackwell Publishers Ltd.,wydanie polskie pod red. J. Czapińskiego, Jacek Santorski \& Co., Warszawa 2001.

[29] Raub S., Does Bureaucracy kill individual initiative? The impact of structure on organizational citizenship behavior in the hospitality industry, „International Journal of Hospitality Mangement” 27/2 (2008), s. 179-186.

[30] Reiter-Palmon R., Illies J.J., Leadership and creativity: Understanding leadership from a creative problem-solving perspective, „The Leadership Quarterly” 2004/15, s. 55-77.

[31] Shalley Ch.E., Gilson L.L., What leaders need to know: A review of social and contextual factors that can foster or hinder creativity, „The Leadership Quarterly”, 15/1 (2004), s. 33-53.

[32] Shalley Ch.E., Zhou J., Oldham G.R., The effects of personal and contextual characteristics on creativity: where should we go from here?, „Journal of Management” 30/6 (2004), s. 933958.

[33] Simons T., Motivation research in hospitality between 1990 and 2001: a prescriptive review of the literature, [w:] Managing employee attitudes and behaviors in the tourism and hospitality industry, red. S. Kusluvan, Nova Publishers, NY 2003.

[34] Simons T., Enz C.A., Motivating hotel employees, „Cornell Hotel and Restaurant Administration Quarterly” 36/1 (1995), s. 20-27.

[35] Siu V., Tsang N., Wong S., What motivates Hong Kong Hotel employees?, „Cornell Hotel and Restaurant Administration Quarterly” 38/5 (1997), s. 44-49.

[36] Trompenaars F., Kultura innowacji. Kreatywność pracowników a sukces firmy, Wolters Kluwer Polska, Warszawa 2010.

[37] Wang C.-J., Tsai H.-T., Tsai M.-T., Linking transformational leadership and employee creativity in the hospitality industry: The influences of creative role identity, creative self-efficacy, and job complexity, „Tourism Management” 2014/40, s. 79-89.

[38] Wieke T., Kreatywność i Ty. Droga do pomystowości w pracy, Helion, Gliwice 2007.

[39] Wong S., Pang L., Motivators to creativity in the hotel industry - perspectives of managers and supervisors, „Tourism Management” 24/5 (2003), s. 551-559.

[40] Wong S.C.-K., Ladkin A. Exploring the relationship between employee creativity and job related motivators in The Hong Kong hotel industry, „International Journal of Hospitality Management” 27/3 (2008), s. 426-437.

[41] Zhou J., George J.M., When Job Dissatisfaction Leads to Creativity: Encouraging the Expression of Voice, „Academy of Management Journal” 44/4 (2001), s. 682-696.

\section{MOTIVATION AND CREATIVITY OF HUMAN RESOURCES IN HOSPITALITY INDUSTRY. ANALYSE OF THE CASE STUDY OF THE SELECTED HOTEL IN TRICITY DESTINATION}

The aim of this study was to investigate the relationship between motivation and creativity on the case of the employees in selected hotel in Tricity destination. The research problem was to seek the answers to the question: what are the motivational determinants of hotel employees' creativity. Research methods applied in the study were critical analysis of the literature in the area of research problem and empirical studies, which were carried out by using an anonymous survey among employees of Tricity hotel that agreed to participate in the research.

Results of the study indicate that in determining hotel employees' creativity, important role is played by intrinsic job-related motivators. Motivational factors, such as interesting work and feeling of being involved appeared to be the significant motivators that enhance respondents' creativity in the work setting; conversely extrinsic motivators, such as job security and tactful disciplining, negatively influence on hotel employees' creativity. 
The research is the case study analysis, so its results should not be generalized; it can be treated as a pilot test of research assumptions and research tool. Despite this, the study results provide some important information for substantive discussion and the context for a wider range of further studies. Implications for managers are also formulated and process of job enrichment is suggested under management consideration to make work more interesting and involving; these both aspects were extremely important for creativity and simultaneously weren't motivational priorities towards actual work in respondents' indications.

Keywords: hospitality industry, motivation , creativity, employees

DOI: 10.7862/rz.2014.mmr.16

Tekst złożono w redakcji: maj 2014

Przyjęto do druku: czerwiec 2014 